\title{
Kajian Pemanfaatan Data Google Maps untuk Pemenuhan Variabel Jumlah dan Jarak Infrastruktur PODES Studi Kasus di Kota Yogyakarta
}

\author{
(Study of The Use of Google Maps Data to Fulfill The Number and Distance of Infrastructure \\ Variable of PODES-Case Study in Yogyakarta City)
}

\author{
Masyitah Ayuning Setyo ${ }^{1 *}$, Waris Marsisno ${ }^{2}$ \\ ${ }^{1,2}$ Politeknik Statistika STIS \\ Jl. Otto Iskandardinata No. 64C, Jakarta Timur 13330 \\ E-mail: 221709818@stis.ac.id
}

\begin{abstract}
ABSTRAK
Statistik Potensi Desa (PODES) merupakan produk Official Statistics yang pada umumnya dihasilkan dari kegiatan pemutakhiran menjelang dilaksanakannya suatu Sensus oleh Badan Pusat Statistik. Variabel yang relatif banyak ditanyakan pada kuesioner PODES adalah jumlah dan jarak infrastruktur yang terdapat di suatu desa. Variabel-variabel ini digunakan untuk penyusunan berbagai indeks, sehingga di-update setiap tahunnya di luar tahun pendataan PODES. Di sisi lain, ketersediaan Big Data memiliki potensi untuk memudahkan pemutakhiran data PODES. Salah satu sumber dari Big Data yang memiliki potensi untuk dimanfaatkan dalam pemutakhiran PODES adalah Google Maps. Penelitian ini dilakukan untuk mengetahui pola dan keakuratan data yang dihasilkan oleh Google Maps. Pengumpulan data infrastruktur dilakukan dengan pembangunan web-scraper dengan Bahasa Python untuk studi kasus pada wilayah Kota Yogyakarta. Dari penelitian ini ditemukan bahwa proses pengumpulan dan pre-processing data membutuhkan waktu dan proses yang lama dan secara umum memiliki tingkat akurasi data yang masih rendah untuk mengestimasi jumlah infrastruktur per desa. Sedangkan untuk akurasi dari titik koordinat Google Maps sudah relatif baik, namun variabel jarak yang diinformasikan oleh Google Maps masih memerlukan penelitian lanjutan ke lapangan. Selain itu, ditemukan bahwa data Google Maps belum dapat mengidentifikasi secara langsung infrastruktur puskesmas dan pasar sesuai kebutuhan dalam PODES. Berdasarkan temuan dari penelitian ini, disimpulkan bahwa Google Maps belum dapat dimanfatkaan untuk pemenuhan variabel jumlah dan jarak infrastruktur pada PODES.
\end{abstract}

Kata kunci: big data, google maps, official statistics, PODES

\begin{abstract}
Village Potential Statistics (PODES) is an Official Statistics product which is generally produced from updating activities prior to the implementation of a Census by the Statistics Indonesia (Badan Pusat Statistik, Central Bureau of Statistics). The variables that are frequently asked in the PODES questionnaire are the number and distance of infrastructures available in a village. These variables are used for the preparation of various indices, so they are updated every year apart from the PODES data collection year. On the other hand, the availability of Big Data has the potential to facilitate updating of PODES data. One source of Big Data that has the potential to be utilized in PODES updates is Google Maps. This research was conducted to examine the pattern and accuracy of the data generated by Google Maps. The infrastructure data collection was carried out by developing a web-scraper in Python for a case study in the Yogyakarta City area. From this study it was found that the process of collecting and pre-processing data takes a long time and process and in general has a low level of data accuracy in estimating the amount of infrastructure per village. While, the accuracy of the coordinates of Google Maps is relatively good, but the distance variable that is informed by Google Maps still requires further field research. In addition, it was found that Google Maps Data has not been able to directly identifiy the infrastructure of public health center (puskesmas) according to the needs in PODES. Based on the findings of this study, it was concluded that Google Maps could not be used to fulfill the number and distance of infrastructure variable in PODES.
\end{abstract}

Keywords: big data, google maps, official statistics, PODES

\section{PENDAHULUAN}

Salah satu statistik yang dihasilkan oleh BPS adalah Statistik Potensi Desa Indonesia yang menyajikan hasil pendataan potensi desa (PODES) berupa data ketersediaan infrastruktur, potensi sosial dan ekonomi (Badan Pusat Statistik, 2018a). Data PODES dikumpulkan melalui metode survei lengkap (sensus) terhadap seluruh kabupaten/kota, kecamatan, dan wilayah administrasi pemerintahan terendah setingkat desa (wilayah administrasi setingkat desa yang dimaksud, yaitu: desa, kelurahan, nagari di Sumatera Barat, Unit Permukiman 
Transmigrasi (UPT), dan Satuan Permukiman Transmigrasi (SPT) yang masih dibina oleh kementerian terkait) (Badan Pusat Statistik, 2018b).

Pada tingkat desa, aparatur desa bertindak sebagai responden yang akan menjawab pertanyaan kuesioner PODES (Badan Pusat Statistik, 2018a). Variabel jumlah dan jarak infrastruktur merupakan variabel yang relatif banyak ditanyakan dalam kuesioner PODES, yaitu sejumlah 47 rincian pertanyaan tentang jumlah infrastruktur dan 34 rincian pertanyaan tentang jarak infrastruktur. Jika suatu infrastruktur tidak tersedia di desa tersebut, selanjutnya ditanyakan variabel jarak yang diisikan dengan jarak antara kantor desa dengan infrastruktur sejenis di desa terdekat. Variabel jumlah dan jarak infrastruktur merupakan variabel yang relatif banyak di tanyakan pada kuesioner PODES. Jika suatu infrastruktur tidak tersedia di desa tersebut, selanjutnya ditanyakan variabel jarak yang diisikan dengan jarak antara kantor desa dengan infrastruktur sejenis di desa terdekat. Kedua variabel ini diperlukan dalam penyusunan Indeks Kesulitan Geografis (IKG) yang menjadi salah satu variabel pengalokasian Dana Desa. Selain IKG, variabel jumlah dan jarak juga diperlukan untuk menyusun Indeks Pembangunan Desa serta Daerah Dalam Angka. Karena mendesaknya kebutuhan data PODES yang terkini untuk setiap tahun, maka BPS juga melakukan pemutakhiran data PODES setiap tahun di luar tahun pendataan PODES.

Perkembangan teknologi informasi yang pesat mengakibatkan terciptanya triliunan data setiap hari melalui berbagai sumber. Data yang berjumlah sangat besar dan kompleks ini mengacu pada sebuah istilah yang disebut Big Data. Menurut De Mauro, Greco, dan Grimaldi (2015), Big Data sebagai aset informasi dapat ditransformasikan menjadi informasi yang bernilai dengan menggunakan teknologi dan metode analisis tertentu. Kemudian, Shukla, Kukade, dan Mujawar (2015) menyebutkan bahwa Big Data memiliki enam karakteristik: Volume (berukuran sangat besar), Variety (datanya sangat beragam), Velocity (memiliki kecepatan akses data yang memadai), Veracity (memiliki bentuk data yang dapat dianalisis), Variability (keberagaman data), dan Visualization (kemudahan memproses dan menafsirkan data). Big Data dapat dijadikan sebagai alternatif sumber data sebagaimana diusulkan pada $45^{\text {th }}$ Session of the United Nation Statistical Commission (2014). Pada bulan Juni tahun 2013, tim tugas Big Data dari United Nations Economic Commission for Europe (UNECE) menetapkan klasifikasi dari tipe-tipe Big Data menjadi tiga jenis, yaitu social networks (human-sourced information), traditional business systems (process-mediated data), dan Internet of Things (machine-generated data) (Vale \& Gjaltema, 2020). Beberapa klasifikasi yang termasuk pada kelompok Internet of Things (machine-generated data) adalah mobile phone location (dengan kode 3121) dan satellite images (dengan kode 3123).

Google Maps merupakan aplikasi peta online gratis yang disediakan oleh Google. Pada Google Maps Platform disebutkan bahwa data Google Maps diperbaharui setiap harinya, baik melalui citra satelit, street view, ataupun dari pengguna Google Maps. Kontribusi pengguna bahkan mencapai 20 juta informasi setiap harinya atau 200 kontribusi setiap detiknya. Patrick (2016) menyebutkan bahwa sumber data utama Google Maps berasal dari smartphone para penggunanya, yaitu data GPS. Hal ini memungkinkan Google Maps menjadi bagian dari salah satu sumber Big Data. Berdasarkan hal tersebut sangat memungkinkan untuk memanfaatkan Google Maps dalam mendukung proses produksi Official Statistics, yakni memberikan kemudahan dalam melaksanakan pemutakhiran data PODES yang harus dilaksanakan setiap tahunnya.

Praktik Kerja Lapangan (PKL) oleh Mahasiswa Tingkat Tiga DIV Politeknik Statistika STIS Tahun Ajaran 2019/2020 yang dilaksanakan pada bulan Maret 2020 di Provinsi Daerah Istimewa Yogyakarta antara lain menghasilkan Buku 11 Laporan Hasil PKL 2019/2020 yang salah satu kesimpulannya menyebutkan bahwa Big Data dari informasi Google Maps dapat dijadikan sebagai rujukan dan pelengkap isian yang berkaitan dengan jumlah dan jarak infrastruktur pada pendataan PODES. Berdasarkan hal tersebut Subdirektorat Statistik Ketahanan Wilayah BPS yang menangani Statistik Potensi Desa mencanangkan pemanfaatan Google Maps untuk pemenuhan variabel jumlah dan jarak infrastruktur pada data PODES. Namun terdapat keterbatasan pada kajian Praktik Kerja Lapangan tersebut, yakni baru mencakup verifikasi dan analisis data Google Maps terhadap 22 infrastruktur dari 47 isian pendataan PODES yang berkaitan dengan infrastruktur pada suatu desa. Sehingga, belum diketahui analisis pemanfaatan Google Maps untuk seluruh variabel jumlah dan jarak infrastruktur pada kuesioner PODES.

Selain itu, Google Maps mengizinkan penggunanya untuk berkontribusi dalam menambahkan informasi geografis seperti melakukan penandaan lokasi melalui fitur "Add Place", melakukan pengeditan peta agar tetap akurat melalui fitur "Edit Map", dan menuliskan review ke lokasi-lokasi yang dikunjungi. Fitur "Add Place" ini dapat menyebabkan adanya satu lokasi yang memiliki dua atau lebih penandaan yang berbeda karena ditandai oleh banyak pengguna. Hal ini akan menyebabkan adanya double counting jika digunakan dalam penghitungan variabel jumlah infrastruktur di suatu desa. Masalah lainnya adalah kemungkinan infrastruktur yang lewat cacah karena tidak memperoleh penandaan dari pengguna Google Maps. Untuk melakukan penandaan lokasi, pengguna Google Maps perlu menentukan titik lokasi yang akan dimasukkan, hal ini dapat 
menyebabkan lokasi pada Google Maps tidak sesuai dengan lokasi yang sebenarnya, sehingga akan mempengaruhi keakuratan jika digunakan dalam pemenuhan variabel jarak. Berdasarkan hal tersebut, perlu adanya kajian lebih mendalam terkait keakuratan data yang ada di Google Maps untuk mengetahui seberapa baik data yang dihasilkan oleh Google Maps untuk dijadikan sebagai sumber data dalam pemenuhan variabel jumlah dan jarak infrastruktur pada data PODES.

Pertanyaan penelitian yang akan dijawab dalam penelitian ini adalah apakah Google Maps dapat dimanfaatkan sebagai sumber data dalam pemenuhan variabel jumlah dan jarak pada PODES, dimana pada penelitian ini ditujukan untuk mengetahui tingkat akurasi titik koordinat data Google Maps serta akurasi datanya untuk dijadikan pemenuhan variabel jumlah dan jarak infrastruktur pada PODES dan mengetahui kemampuan data Google Maps dalam mengidentifikasi perbedaan antara infrastruktur sejenis yang berbeda fasilitas/bangunan fisik.

\section{METODE}

\section{Cakupan Penelitian}

Penelitian ini terbatas pada analisis keakuratan data Google Maps yang berkaitan dengan variabel jumlah dan jarak infrastruktur di dalam kuesioner PODES dan analisis berbagai kendala yang terjadi di setiap tahap pengumpulan. Unit analisis dalam penelitian ini adalah infrastruktur dengan variabel yang diamati berupa informasi detail infrastruktur dan jaraknya menuju kantor desa untuk 45 desa pada Kota Yogyakarta. Infrastruktur yang dicakup dalam penelitian ini terdiri dari lima infrastruktur (pendidikan, kesehatan, tempat ibadah, ekonomi, dan lembaga keuangan) yang sesuai dengan 47 rincian pertanyaan pada kuesioner PODES yang dikembangkan menjadi 71 kata kunci untuk pencarian pada Google Maps.

\section{Data dan Sumber Data}

Penelitian ini memanfaatkan metode web-scraping untuk mengumpulkan data infrastruktur dari Google Maps. Metode web-scraping dipilih karena peneliti menguasai metode tersebut dan relatif mudah untuk digunakan. Menurut Banerjee (2014), terdapat lima keuntungan penggunaan web-scraping, yakni biaya yang kecil, hemat waktu, hasil akurat, kompetitif, dan berkualitas tinggi. Pada penelitian ini, web-scraper dijalankan dengan menggunakan bahasa Python 3.7 pada IDE Jupyter Notebook dengan memanfaatkan Library Selenium. Pengumpulan menggunakan web-scraping terdiri dari tiga tahap, yaitu:

Tahap 1: Pengumpulan URL kantor desa

Pada tahap ini dilakukan otomatisasi web-scraping melakukan pencarian URL kantor desa di Google Maps dengan menggunakan kata kunci "https://www.google.com/maps/search/kantor + desa + [namadesa]". Dimana [namadesa] diisikan dengan nama desa bersangkutan + kecamatan + kabupaten/kota.

Tahap 2: Pengumpulan URL kata kunci infrastruktur

Di tahap dua web-scraper melakukan pengumpulan URL 71 kata kunci pada masing-masing desa dengan memanfaatkan fitur "nearby" pada Google Maps. URL ini merupakan URL yang menampilkan laman hasil pencarian di Google Maps berdasarkan kata kunci.

Tahap 3:Pengumpulan detail informasi penandaan

Pada tahap tiga web-scraper mengakses URL pada tahap dua dan mengumpulkan detail informasi dari 40 hasil pencarian pertama. Informasi yang dikumpulkan dari setiap penandaan pada Google Maps yaitu nama penandaan, alamat, kode plus, rating, ulasan, titik koordinat, serta jarak dan durasi penandaan ke kantor desa.

Selain data dari hasil pengumpulan web-scraping, penelitian ini juga menggunakan data jumlah dan jarak infrastruktur dari hasil pendataan PODES 2018 dan 2020 serta data Geotagging dari Badan Pusar Statistik yang digunakan sebagai data pembanding dengan hasil web-scraping.

\section{Metode Analisa Data}

Metode analisis yang digunakan dalam penelitian ini adalah analisis deskriptif, yaitu untuk menggambarkan langkah serta kendala dalam pengolahan data Google Maps, menggambarkan tingkat akurasi data Google Maps untuk pemenuhan variabel jumlah dan jarak infrastruktur pada PODES serta akurasi titik koordinat penandaan dan mendeskripsikan kemampuan data Google Maps dalam mengidentifikasi perbedaan antara infrastruktur sejenis yang berbeda fasilitas/bangunan fisik.

1. Perhitungan persentase tingkat akurasi data Google Maps untuk pemenuhan variabel jumlah infrastruktur. 
Sebelum perhitungan persentase dilakukan perhitungan pencocokan antara data Google Maps dengan sumber data lain dengan persamaan berikut: dimana:

Selisih $=$ SumberLain $_{i j}-$ Google $_{i j}$

Selisih : Nilai selisih data jumlah infrastruktur Google Maps dengan sumber data lain

SumberLain $_{i j} \quad:$ jumlah infrastruktur pada sumber data lain untuk kelompok i pada desa $\mathrm{j}$

Google $_{i j} \quad:$ jumlah infrastruktur pada data Google Maps untuk kelompok i pada desa j

Hasil dari perhitungan menggunakan persamaan (1) dikelompokkan menjadi tiga kategori, yaitu:

a. Selisih bernilai dibawah nol (Selisih $<0$ ), yang berarti data Google Maps overestimate

b. Selisih bernilai nol $\left(\right.$ Selisih $\left._{0}\right)$, yang berarti data Google Maps memiliki jumlah infrastruktur tepat sama dengan data lainnya

c. Selisih bernilai di atas nol $\left(\right.$ Selisih $\left._{>0}\right)$, yang berarti data Google Maps underestimate

Kemudian persentase tingkat akurasi data Google Maps dihitung dengan banyaknya desa yang masuk dalam tiga kategori tersebut sesuai persamaan berikut ini:

$$
P S_{a}=\frac{\operatorname{Count}_{\left(\text {Selisih }_{a}\right)}}{\text { total ketiga kategori }}
$$

dimana:

$P S_{a} \quad:$ Persentase banyaknya desa pada kelompok Selisih $a$, dimana $a$ adalah selisih di bawah nol atau sama dengan nol atau di atas nol

Count $\left(\right.$ Selisih $\left._{a}\right)$ : banyaknya desa pada kelompok Selisih $a$ pada jenis infrastruktur yang sama

Persentase pada kategori Selisi $h_{0}$ menunjukkan tingkat akurasi data Google Maps, dimana jika bernilai tinggi menunjukkan tingkat akurasi yang juga tinggi.

2. Perhitungan tingkat akurasi kesesuaian titik koordinat data Google Maps

Sebelum perhitungan tingkat akurasi kesesuaian titik koordinat dilakukan perhitungan jarak antara dua titik koordinat, yaitu koordinat data Google Maps dengan data Geotagging, dimana jika jarak antara kedua titik koordinat bernilai nol artinya tepat sama. Jarak antara dua titik koordinat tersebut dihitung dengan menggunakan Algoritma Haversine berikut ini:

dimana:

$$
d=2 r \arcsin \left(\sqrt{\sin ^{2}\left(\frac{\Delta l a t}{2}\right)+\cos (\text { lat } 1) \cdot \cos (\text { lat } 2) \cdot \sin ^{2}\left(\frac{\Delta l o n}{2}\right)}\right)
$$

$$
\begin{array}{lll}
d & : & \text { Jarak } \\
r & : & \text { jari-jari bumi }(6.371 \mathrm{~km}) \\
\Delta l a t & : & \text { besaran perubahan latitude } \\
\text { slon } & : & \text { besaran perubahan longitude }
\end{array}
$$

Tingkat akurasi titik koordinat dihitung dari besarnya persentase jarak yang berada pada rentang nol hingga dua kilometer.

3. Tingkat akurasi data Google Maps untuk pemenuhan variabel jarak infrastruktur

Tingkat akurasi data jarak Google Maps dihitung dari sebaran data selisih jarak antara data jarak Google Maps dengan data jarak haversine dari infrastruktur pada data Geotagging. Dimana jarak haversine ini dihitung menggunakan persamaan (3). Perhitungan selisih selisih antara jarak data Google Maps dengan jarak haversine data Geotagging menggunakan rumus berikut: dimana:

Selisih Jarak = JarakGeotagging -JarakGoogle

$$
\begin{array}{lll}
\text { Selisih Jarak } & : & \text { Nilai selisih jarak haversine data Geotagging dengan jarak data Google Maps } \\
\text { JarakGeotagging } & : & \text { Jarak infrastruktur pada data Geotagging menuju kantor desa yang dihitung } \\
\text { JarakGoogle } & : & \text { data jarak yang didapatkan dari Google Maps }
\end{array}
$$

\section{HASIL DAN PEMBAHASAN}

\section{Analisis Proses Pengumpulan Data}

Pengumpulan data menggunakan dengan web-scraping terbagi menjadi tiga tahapan yang sudah dijelaskan pada bagian metodologi. Pada pengumpulan tahap satu menghabiskan waktu rata-rata 13,8 detik untuk satu kantor desa. Pada tahap ini terdapat beberapa desa yang tidak berhasil dikumpulkan URL-nya dan juga terdapat URL yang tidak tepat. Hal ini disebabkan karena adanya pengaruh dari koneksi internet dan 
spesifikasi perangkat yang digunakan. Penggunaan koneksi internet yang lebih cepat dan spesifikasi perangkat yang lebih canggih dapat mengumpulkan data yang lebih akurat. Sedangkan untuk URL yang tidak tepat juga disebabkan karena pada saat melakukan pencarian, web-scraping mengumpulkan penandaan lain yang memenuhi algoritma kesesuaian suatu penandaan dengan kantor desa yang dicari. Sedangkan, untuk pengumpulan tahap dua menghabiskan waktu rata-rata 13,53 detik untuk satu desa dan total 10,15 menit untuk seluruh desa di Kota Yogyakarta serta dikumpulkan 3690 URL. Selanjutnya untuk pengumpulan tahap tiga menghabiskan waktu kurang lebih 7 jam untuk satu desa dan 13 hingga 14 hari untuk seluruh desa di Kota Yogyakarta, serta dikumpulkan sebanyak 117.799 penandaan Google Maps.

\section{Analisis Proses Pre-processing Data}

Terdapat empat tahap pre-processing yang dilakukan agar data bisa digunakan, yaitu:

1. Penghapusan penandaan yang berada di luar desa bersangkutan

Adanya penandaan yang berada di luar desa yang bersangkutan dikarenakan hasil pencarian pada Google Maps tidak diurutkan berdasarkan jarak terdekat dari kantor desa. Penghapusan dilakukan untuk obyek yang koordinat penandaannya berada di luar wilayah administratif desa. Pengecekan dilakukan dengan library "Shapely" pada Python. Dari pre-processing tahapan ini ditemukan sebanyak 96,19 persen data penandaan yang tidak berada pada desa yang bersangkutan dan hanya ada 3,81 persen (4.485 penandaan) yang benar.

2. Pengelompokan data

Pengelompokan data dilakukan untuk mempermudah tahapan pre-processing selanjutnya. Pengelompokan ini didasarkan pada pertanyaan yang terdapat pada kuesioner PODES yaitu menjadi 43 kelompok data.

3. Penghapusan duplikasi data

Pada data yang dikumpulkan ditemukan adanya tiga kasus duplikasi yang berbeda, yaitu (a) duplikasi penandaan yang sama karena terambil lebih dari sekali, (b) duplikasi penandaan yang sama karena muncul pada kata kunci yang berbeda namun masih dalam satu kelompok pertanyaan yang sama pada kuesioner PODES, dan (c) duplikasi objek yang sama namun memiliki banyak penandaan yang berbeda. Penghapusan duplikasi kasus (a) dan (b) dilakukan dengan library "Pandas" pada Python. Sedangkan penanganan duplikasi (c) dilakukan secara manual dengan pemeriksaan satu per satu data ke laman Google Maps dan diidentifikasi secara subjektif melalui foto yang tersedia di Google Maps atau melihat kedekatan titik penandaan untuk melihat apakah ada penandaan-penandaan merujuk pada satu objek yang sama.

Proporsi duplikasi kasus (a) mencapai 14,18 persen dengan persentase tertinggi pada kelompok tempat ibadah (Gambar 1(a)). Sedangkan duplikasi kasus (b) mencapai 13,67 persen dengan persentase tertinggi pada infrastruktur ekonomi (Gambar 1(b)).

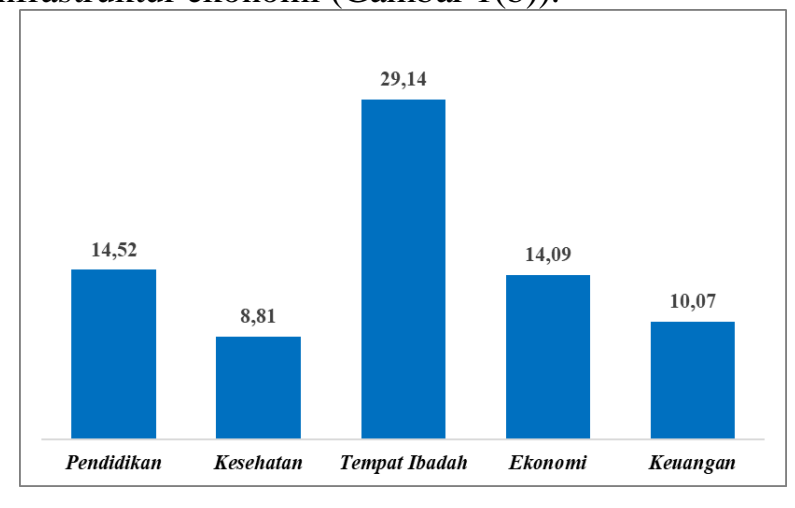

(a)

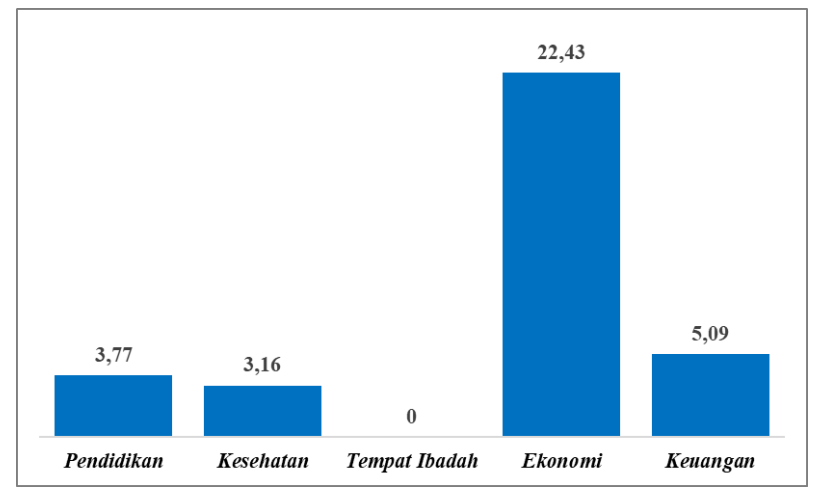

(b)

Gambar 1. Persentase duplikasi kasus (a) dan (b) menurut kelompok infrastruktur.

Duplikasi kasus (c) mencapai 3,61 persen dengan 113 objek yang memiliki penandaan lebih dari satu kali pada Google Maps, yaitu 107 objek memiliki dua penandaan, 5 objek dengan tiga penandaan, dan 1 objek memiliki empat penandaan (Gambar 2). 


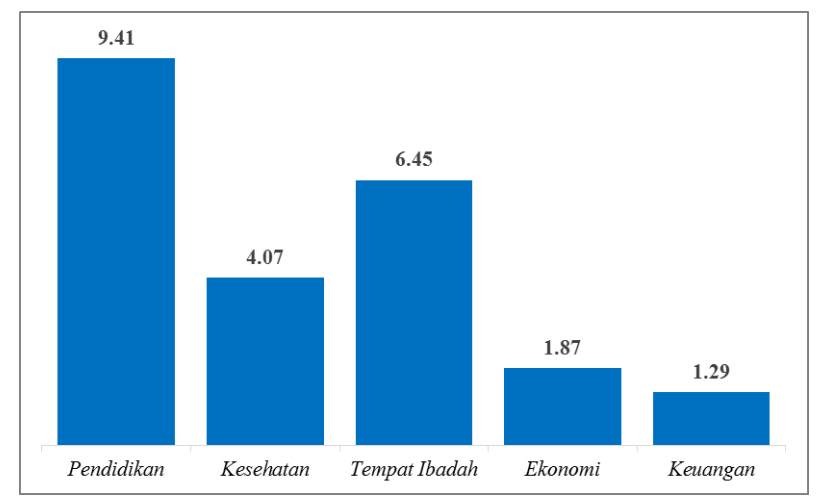

Gambar 2. Persentase duplikasi kasus (c) menurut kelompok infrastruktur.

Terdapat beberapa pola duplikasi (c) yang ditemukan pada masing-masing kelompok infrastruktur sebagai berikut:

a. Infrastruktur Pendidikan

Kelompok TK/RA/BA memiliki jumlah duplikasi terbanyak, dimana 5 dari 8 duplikasi yang disebabkan oleh penggunaan singkatan untuk nama infrastruktur. Ditemukan 3 dari 8 duplikasi pada kelompok SD/MI dan 1 dari 6 duplikasi pada kelompok SMA/MA yang disebabkan oleh perbedaan kelengkapan informasi. Juga terdapat 2 duplikasi yang disebabkan oleh perbedaan informasi tentang fasilitas yang ada di sekolah. Sedangkan untuk kelompok Akademi/Perguruan Tinggi, ditemukan 3 dari 6 duplikasi disebabkan karena adanya penandaan dengan tambahan nama jurusan pada suatu akademi/perguruan tinggi.

b. Infrastruktur Kesehatan

Sebanyak. 6 dari 7 duplikasi pada Kelompok Rumah Sakit disebabkan oleh perbedaan penandaan untuk fasilitas yang ada pada rumah sakit.

c. Tempat Ibadah

Pada tempat ibadah tidak memperlihatkan pola tertentu. Untuk nama masjid seringkali muncul duplikasi karena perbedaan nama dalam Bahasa Indonesia dan Bahasa Arab.

d. Infrastruktur Ekonomi

Kelompok Penginapan memiliki jumlah duplikasi terbanyak. Duplikasi pada kelompok ini umumnya terjadi karena adanya perbedaan nama penandaan fasilitas yang ternyata merujuk pada obyek yang sama.

e. Infrastruktur Lembaga Keuangan

Duplikasi pada Bank, baik itu bank pemerintah maupun bank swasta, 4 dari 6 duplikasi ditemukan memiliki penamaan yang general, contohnya "PT Bank Negara Indonesia (Persero)" atau "BCA Syariah".

Walaupun penghapusan data pada duplikasi kasus (c) relatif memakan waktu dan memerlukan ketelitian yang sangat tinggi, langkah pemeriksaan di Google Maps tetap harus dilakukan karena pada data yang dikumpulkan terdapat 22,81 persen data yang terduplikasi memiliki penamaan yang jauh berbeda dan tidak dapat diidentifikasi hanya dari nama penandaan, namun harus diidentifikasi berdasarkan foto atau letak titik koordinat yang terdapat di Google Maps. dan hasilnya akan sangat subjektif berdasarkan kesimpulan petugas yang menangani. Namun, ditemukan beberapa pola yang dapat memudahkan proses pre-processing data, yakni:

a. Ditemukan sebanyak 10 persen duplikasi karena penamaannya terlalu umum, tanpa informasi spesifik. Misal "Warung Kelontong", "Gereja Kristen Jawa", "Toko Jamu”, dan sebagainya.

b. Ditemukan sebanyak 77,19 persen duplikasi yang disebabkan oleh penandaan dengan nama yang mirip. Untuk kasus ini tinggal dihapus penandaan dengan jumlah ulasan/komentar yang lebih sedikit. 4. Penghapusan penandaan yang tidak sesuai dengan kata kunci

Proses pengecekannya dilakukan bersamaan dengan pemeriksaan duplikasi kasus 3(c). Ditemukan sebanyak 38,4 persen penandaan yang tidak sesuai dengan kata kunci. Berikut adalah pola ketidaksesuaian penandaan dengan kata kunci yang ditemukan pada masing-masing kelompok infrastruktur:

a. Infrastruktur pendidikan

Dari 17 total penandaan yang tidak sesuai, sebanyak 64,7 persen dikarenakan salah dalam mengidentifikasi tingkatan sekolah.

b. Infrastruktur kesehatan 
Dari 145 penandaan yang tidak sesuai untuk infrastruktur kesehatan, ditemukan 82,76 persen data yang salah mengidentifikasi fasilitas kesehatan, 6,2 persen penandaan kantor yang berkaitan dengan Kesehatan, dan 11,03 persen merupakan penandaan yang tidak berhubungan dengan kesehatan.

c. Tempat ibadah

Pada kelompok masjid 71,42 persen ketidaksesuaian merupakan penandaan terhadap sekolah dibawah yayasan suatu masjid dan pada penamaannya terdapat kata "masjid", salah satu contohnya adalah "TK Masjid Syuhada" dan 28,57 persen lainnya merupakan penandaan terhadap lembaga zakat. Sedangkan untuk kelompok tempat ibadah lainnya tidak ditemukan pola tertentu.

d. Infrastruktur ekonomi

Kelompok Restoran/Rumah Makan memiliki jumlah kesalahan paling banyak, kemudian diikuti oleh kelompok Minimarket/Swalayan. Pola yang ditemukan pada infrastruktur ekonomi adalah kecenderungan dari pengguna Google Maps saat melakukan penandaan terhadap warung/kedai makanan dengan memasukkannya pada kategori restoran/rumah makan, yakni ditemukan sebanyak 76,63 persen warung/kedai makanan atau pedagang kaki lima ditandai sebagai restoran/rumah makan pada Google Maps. Begitu juga untuk warung/toko yang menjual barang keseharian, pengguna Google Maps cenderung memasukkannya pada kategori Minimarket atau Swalayan saat melakukan penandaan pada Google Maps, yaitu ditemukan sebanyak 54,86 persen.

e. Infrastruktur lembaga keuangan

Dari 314 penandaan yang tidak sesuai pada Lembaga Keuangan 76,75 persen dikarenakan adanya penandaan ATM; 21,66 persen dikarenakan adanya bank umum atau BPR yang masuk pada kelompok bank swasta dan sebaliknya dan sisanya penandaan pada objek lain.

\section{Analisis Identifikasi Infrastruktur Puskesmas dan Pasar}

Informasi yang ditanyakan untuk infrastruktur puskesmas dan pasar dalam kuesioner PODES memiliki rincian yang lebih banyak dibandingkan fasilitas lain. Untuk puskesmas ditanyakan lebih lanjut tentang keberadaan puskesmas dengan fasilitas rawat inap, tanpa rawat inap, dan puskesmas pembantu. Sedangkan untuk infrastruktur pasar ditanyakan keberadaan pasar dengan bangunan permanen, semi permanen, dan tanpa bangunan. Pada pengumpulan data, masing-masing pertanyaan tersebut diwakili oleh satu kata kunci pencarian, kemudian peneliti menambahkan kata kunci untuk menggambarkan semua infrastruktur tersebut secara umum yakni dengan kata kunci "puskesmas" dan "pasar" saja. Karena adanya penambahan kata kunci ini, proses pre-processing data dilakukan secara terpisah untuk infrastruktur puskesmas dan pasar.

a. Puskesmas

Pada pencarian menggunakan kata kunci "puskesmas rawat inap" didapatkan 8 penandaan setelah dilakukan penghapusan untuk duplikasi kasus (a). Dari 8 penandaan ini fasilitas puskesmas tidak dapat diidentifikasi dari penamaannya saja, kemudian setelah dilakukan penghapusan untuk duplikasi kasus (b) dan (c) serta penandaan yang tidak sesuai, tersisa 1 penandaan yang diidentifikasi sebagai puskesmas yang memiliki pelayanan rawat inap. Untuk pencarian dengan kata kunci "puskesmas tanpa rawat inap" diperoleh 5 penandaan, kemudian setelah dilakukan tahap pre-processing data tersisa 2 penandaan yang diidentifikasi sebagai puskesmas tanpa rawat inap. Sedangkan untuk pencarian menggunakan kata kunci "puskesmas pembantu" diperoleh 11 penandaan dan hanya 8 diantaranya diidentifikasi sebagai puskesmas pembantu setelah dilakukan pemeriksaan lebih lanjut.

Dari ketiga kata kunci yang spesifik dan sesuai dengan pertanyaan kuesioner tersebut, hanya pada data yang dikumpulkan menggunakan kata kunci "puskesmas pembantu" pada penandaannya terdapat keterangan "puskesmas pembantu", sedangkan untuk kata kunci lainnya diidentifikasi secara manual.

Pada pencarian menggunakan kata kunci "puskesmas" didapatkan 28 penandaan dan 7 diantaranya juga ditemukan pada pencarian dengan tiga kata kunci lainnya. Setelah dilakukan pre-processing data, tersisa 17 penandaan pada kata kunci "puskesmas". 17 penandaan ini kemudian diidentifikasi dengan mengunjungi laman Google Maps dengan hasil 14 merupakan puskesmas tanpa rawat inap dan 3 sisanya merupakan puskesmas pembantu.

Berdasarkan penjelasan tersebut memperlihatkan bahwa semakin umum kata kunci yang digunakan, maka hasil pencarian akan semakin relevan. Dan dapat disimpulkan bahwa Google Maps tidak dapat mengidentifikasikan secara langsung puskesmas berdasarkan fasilitasnya meskipun menggunakan kata kunci yang spesifik. Sehingga untuk menggunakan data Google Maps pada rincian pertanyaan mengenai jumlah puskesmas pada PODES lebih baik menggunakan kata kunci yang lebih umum kemudian diidentifikasi melalui foto yang tersedia di laman Google Maps oleh petugas yang menanganinya yang menyebabkan data yang dihasilkan bersifat subjektif. 
b. Pasar

Dari empat kata kunci yang digunakan untuk infrastruktur Pasar, hanya terdapat data untuk kata kunci "pasar tanpa bangunan" dan "pasar". Pencarian menggunakan kata kunci "pasar tanpa bangunan" mendapatkan 95 hasil penandaan. Namun setelah dilakukan pre-processing data, 95 penandaan ini tidak merujuk pada pasar tanpa bangunan di lapangan, dengan rincian sebagai berikut: 41 merujuk pada minimarket/supermarket, 19 pada kantor pos, 13 pada bank, 6 pasar permanen/semi permanen, 6 pada warung/toko, 3 kantor, 2 hotel, 2 asuransi, dan 3 merujuk ke objek lain.

Sedangkan, kata kunci "pasar" menghasilkan 53 penandaan, kemudian 3 penandaan dihapuskan karena duplikasi kasus (c) dan 23 penandaan dihapuskan karena penandaan tidak merujuk pada pasar. Sehingga tersisa 31 penandaan yang kemudian diidentifikasikan ke laman Google Maps. Setelah dilakukan pemeriksaan, 10 penandaan diidentifikasi sebagai pasar dengan bangunan permanen, 11 penandaan sebagai pasar semi permanen, 7 penandaan sebagai pasar tanpa bangunan, dan 3 penandaan tidak dapat diidentifikasi karena tidak ada foto dan ulasan pada Google Maps. Berdasarkan hasil tersebut memperlihatkan bahwa Google Maps tidak bisa mengidentifikasikan perbedaan bangunan dari infrastruktur pasar tanpa dilakukan identifikasi secara manual dan subjektif, serta ada kemungkinan tidak berhasil diidentifikasi karena informasi yang tersedia pada Google Maps terbatas.

\section{Analisis Penggunaan Kata Kunci}

Dari penggunaan 71 kata kunci ditemukan beberapa penggunaan yang tidak efektif. Pertama, pada penggunaan kata kunci "praktik bidan" web-scraper mengumpulkan 1283 penandaan, namun setelah melakukan pre-processing tahap satu (penghapusan penandaan di luar desa) hanya bersisa satu penandaan. Sedangkan dalam proses pre-processing kelompok "rumah sakit bersalin" dan "rumah bersalin" ditemukan enam penandaan tempat praktik bidan. Tidak diketahui penyebab terjadinya hal ini, namun untuk pencarian selanjutnya dapat menggunakan kata kunci "bidan" saja.

Kedua, penggunaan kata kunci "kelompok pertokoan", "pasar bangunan permanen", "pasar bangunan semi permanen", dan "pasar tanpa bangunan" sangat tidak efektif karena pada data dari Google Maps tidak ditemukan penandaan yang sesuai menggunakan kata kunci tersebut. Sehingga untuk penggunaannya Google Maps tidak dapat memenuhi variabel jumlah infrastruktur pada kelompok "kelompok pertokoan" namun untuk pasar masih bisa dipenuhi dengan penggunaan kata kunci "pasar" seperti yang sudah dijelaskan sebelumnya.

\section{Analisis Tingkat Akurasi Data Google Maps dalam Pemenuhan Variabel Jumlah Infrastruktur}

Persentase tingkat akurasi dari data Google Maps dihitung dengan melakukan perbandingan antara data Google Maps dengan data PODES dan Geotagging menggunakan rumus (1) dan (2). Dengan hasil sebagai berikut:

a. Infrastruktur Pendidikan

Tingkat akurasi data Google Maps pada kelompok infrastruktur pendidikan terhadap data PODES 2018, PODES 2020, dan Geotagging berturut-turut sebesar 59,83 persen; 37,46 persen; dan 42,96 persen. Terhadap PODES 2020 dan Geotagging persentase mendominasi pada kelompok selisih di atas nol, yang artinya data Google Maps cenderung underestimate.

b. Infrastruktur Kesehatan

Tingkat akurasi data Google Maps pada kelompok infrastruktur kesehatan terhadap data PODES 2018, PODES 2020, dan Geotagging berturut-turut sebesar 69,40 persen; 71,79 persen; dan 69,26 persen. Tingkat akurasi pada ketiga perbandingan mendekati tujuh puluh persen, hal ini menunjukkan bahwa data Google Maps cukup baik dalam mengestimasi jumlah infrastruktur kesehatan.

c. Tempat Ibadah

Tingkat akurasi data Google Maps pada kelompok tempat ibadah terhadap data PODES 2018, PODES 2020, dan Geotagging berturut-turut sebesar 62,22 persen; 61,90 persen; dan 69,78 persen. Tingkat akurasi pada ketiga perbandingan sudah berada diatas enam puluh persen. Berdasarkan hal tersebut, dapat dikatakan data Google Maps juga cukup baik dalam mengestimasi jumlah infrastruktur tempat ibadah.

d. Infrastruktur Ekonomi

Tingkat akurasi data Google Maps pada kelompok infrastruktur ekonomi terhadap data PODES 2018, PODES 2020, dan Geotagging berturut-turut sebesar 31,33 persen; 27,33 persen; dan 33,09 persen. Persentase mendominasi pada kelompok selisih di atas nol, yakni berturut-turut sebesar 53,11 persen; 63,11 persen; dan 58,52 persen, yang artinya data Google Maps cenderung underestimate.

Data Google Maps untuk infrastruktur ekonomi memiliki tingkat akurasi yang sangat rendah. Hal ini dikarenakan pada pengumpulan data melalui Google Maps hanya dibatasi dengan 40 pencarian teratas di 
setiap desanya, sedangkan kebanyakan pada infrastruktur ekonomi memiliki jumlah diatas 40 infrastruktur pada masing-masing kelompok. Karena keterbatasan inilah pada infrastruktur ekonomi terlihat jarak yang sangat besar antara data Google Maps dengan sumber data lainnya, terlebih pada infrastruktur toko/warung kelontong dan warung/kedai makanan minuman. Sehingga, meskipun persentase tingkat akurasi cukup rendah, tidak dapat diambil kesimpulan bahwa data Google Maps tidak akurat dikarenakan keterbatasan tersebut.

e. Infrastruktur Lembaga Keuangan

Tingkat akurasi data Google Maps pada kelompok infrastruktur lembaga keuangan terhadap data PODES 2018, PODES 2020, dan Geotagging berturut-turut sebesar 48,15 persen; 48,15 persen; dan 48,89 persen.

Dari hasil perbandingan pada kelima infrastruktur yang telah dijelaskan terlihat bahwa tingkat akurasi data Google Maps masih rendah dalam mengestimasi variabel jumlah infrastruktur pada PODES, namun sudah cukup baik untuk tempat ibadah yang persentasenya berada diatas 60 persen dan infrastruktur kesehatan yang persentasenya mendekati 70 persen.

\section{Analisis Tingkat Akurasi Koordinat Titik Penandaan Data Google Maps}

Saat melakukan penandaan di Google Maps sebagian besar pengguna tampaknya tidak meletakkan titik penandaan pada posisi yang tepat. Hal ini tentunya akan mempengaruhi variabel jarak yang diberikan pada Google Maps. Tingkat akurasi dari koordinat titik penandaan di Google Maps dihitung dengan cara mengukur jarak antara koordinat yang dikumpulkan dari Google Maps dengan koordinat pada data Geotagging dengan memanfaatkan Algoritma Haversine. Penghitungan tingkat akurasi ini dilakukan pada seluruh kelompok pertanyaan, kecuali SDLB, SMPLB, SMALB, Pondok Pesantren, Madrasah Diniyah, Seminari, Surau/Langgar/Musala, Kapel, kelompok pertokoan, dan Warung/Kedai Kelontong karena tidak tersedia datanya pada Geotagging atau Google Maps. Kelompok Penginapan, dan Warung/Kedai Makanan Minuman, Bank Umum \& Swasta, dan BPR juga tidak dihitung akurasinya karena datanya memiliki tingkat kecocokan yang tendah.

Jadi, perbandingan hanya dilakukan pada 32 kelompok pertanyaan dengan total data dari hasil scraping Google Maps sebanyak 1.279 infrastruktur sedangkan untuk data geotagging sebanyak 2.805 infrastruktur. Dari 1.279 infrastruktur yang dikumpulkan dari scraping Google Maps hanya ditemukan sebanyak 756 infrastruktur (59,10 persen) yang bersesuaian dengan data hasil Geotagging.

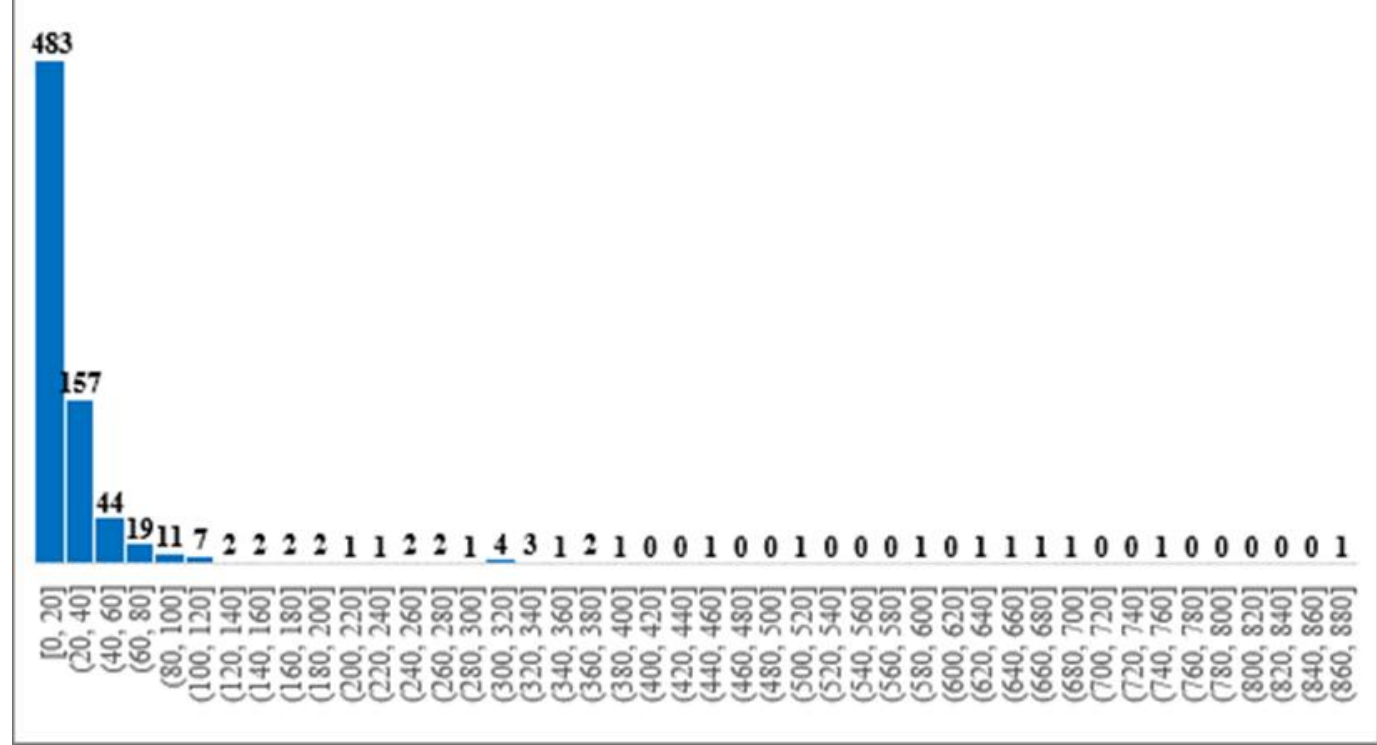

Gambar 3. Jarak antara koordinat data Google Maps dengan data Geotagging

Mengacu ada penelitian yang dilakukan Annisa \& Pramana (2020), jika jarak dari perhitungan haversine kurang dari 2 kilometer, maka dua titik yang diujikan dianggap merupakan objek yang sama, berdasarkan hal tersebut maka seluruh data yang diujikan berada pada rentang nol hingga dua kilometer. Namun jika mengacu dilihat, banyaknya infrastruktur yang berada pada rentang jarak nol hingga 100 meter ada sebanyak 94,44 persen, hal ini menunjukkan koordinat penandaan dari data Google Maps sudah cukup akurat. 


\section{Analisis Tingkat Akurasi Data Google Maps dalam Pemenuhan Variabel Jarak Infrastruktur}

Pada kuesioner PODES, jika suatu desa tidak memiliki infrastruktur tertentu selanjutnya akan ditanyai jarak infrastruktur sejenis terdekat di desa lain. Variabel jarak yang dimaksud merupakan jarak yang diukur dari kantor desa menuju infrastruktur bersangkutan. Google Maps juga memberikan informasi jarak dan durasi dari kantor desa menuju sebuah infrastruktur saat menggunakan fitur "nearby". Untuk mengetahui tingkat akurasi dari informasi jarak yang disediakan oleh Google Maps digunakan rumus (3) dan sebaran hasil perhitungannya dapat dilihat pada Gambar 4. Perbandingan ini dilakukan terhadap 756 infrastruktur yang sama dengan penghitungan akurasi titik koordinat.

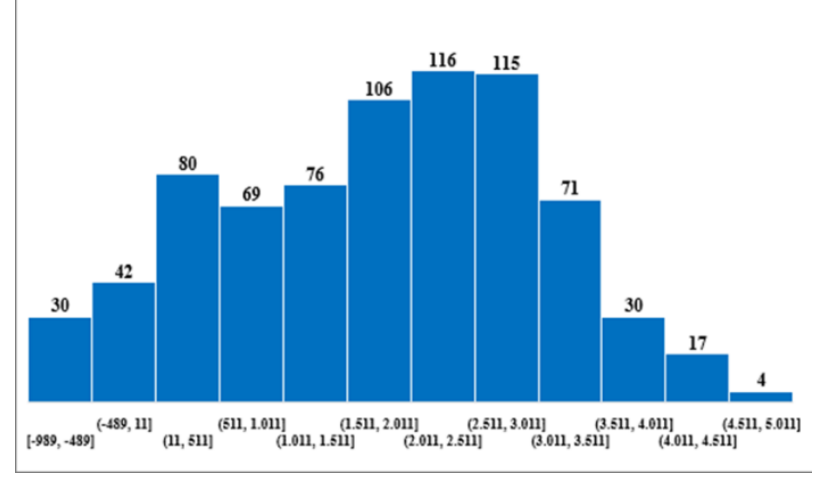

Gambar 4. Sebaran selisih data jarak pada Google Maps dengan jarak haversine pada data Geotagging

Berdasarkan Gambar 4 terlihat bahwa sebaran selisih jarak dominan berada pada rentang 1.500 hingga 3.000 meter dan sebanyak 90,92 persen hasil selisih antara data Geotagging dengan data Google Maps bernilai positif, yang artinya nilai jarak pada Google Maps cenderung lebih kecil daripada jarak pada data Geotagging. Dan hanya terdapat 1,98 persen yang memiliki selisih pada rentang nol hingga 100 meter. Namun, berdasarkan penelitian yang dilakukan oleh Mukarromin \& Nilogiri (2020) yang melakukan perbandingan jarak dari algoritma haversine, Google Maps API, dan jarak sebenarnya yang dihitung menggunakan odometer kendaraan bermotor pada 6 objek, menemukan bahwa MAPE (Mean Absolute Error) dari Google Maps lebih rendah (11 persen) dibandingkan dengan MAPE dari algoritma Haversine (33 persen). Dimana hal ini dikarenakan pada algortima haversine mengambil garis lurus dalam perhitungan jarak sedangkan Google Maps API mengikuti rute jalan terpendek dan hampir sama menyerupai perhitungan secara real (Mukarromin \& Nilogiri, 2020).

Mengacu pada penelitian Mukarromin \& Nilogiri (2020) tersebut, maka perbandingan pada Gambar 4 tidak dapat digunakan untuk menarik kesimpulan bahwa data jarak dari Google Maps memiliki akurasi yang rendah. Berdasarkan penelitian Mukarromin \& Nilogiri (2020) tersebut, terdapat peluang data jarak dari Google Maps memiliki akurasi yang cukup baik, namun harus dilakukan penelitian ke lapangan untuk membandingkan jarak yang sebenarnya dengan jarak pada Google Maps dikarenakan penelitian Mukarromin \& Nilogiri (2020) baru dilakukan untuk 6 objek saja.

\section{Rekomendasi untuk Penggunaan Data Google Maps dalam Pemenuhan Variabel Jumlah dan Jarak Infrastruktur pada PODES}

Tingkat akurasi data dari Google Maps yang telah dikumpulkan untuk variabel jumlah infrastruktur secara umum masih cukup rendah, sedangkan untuk variabel jarak infrastruktur jika dihitung menggunakan algoritma haversine sudah cukup baik. Berikut ini diuraikan beberapa rekomendasi yang bisa dilakukan jika ingin menggunakan data dari Google Maps dalam pemenuhan variabel jumlah dan jarak infrastruktur pada PODES agar dapat meningkatkan akurasi data.

1. Penggunaan Google Maps API

Penggunaan Google Maps API menawarkan berbagai keunggulan dibandingkan dengan metode webscraping, antara lain berupa waktu pengumpulan data yang lebih singkat (5-10 detik per infrastruktur), tidak membutuhkan komputer dengan spesifikasi yang tinggi, tidak membutuhkan koneksi internet yang cepat, dan data dapat dikumpulkan dengan mengurutkan dari yang memiliki jarak terdekat.

2. Jumlah data yang dikumpulkan

Jumlah data yang dikumpulkan dapat disesuaikan dengan jumlah infrastruktur pada masing-masing kelompok berdasarkan pendataan PODES atau data Geotagging, khususnya pada Infrastruktur Ekonomi yang jumlah infrastruktur per kelompok pertanyaannya pada umumnya berjumlah ratusan.

3. Melakukan penandaan dan pengecekan ke lapangan 
Selain untuk meningkatkan akurasi data, pengecekan ke lapangan juga perlu dilakukan untuk melakukan validasi data yang dikumpulkan.

4. Petugas yang menangani pre-processing data

Petugas yang menangani proses pre-processing data sangat direkomendasikan berasal dari daerah yang sama. Hal ini ditujukan agar petugas waspada pada kebiasaan masyarakat pada daerah tersebut yang mungkin mempengaruhi penandaan pada Google Maps.

\section{KESIMPULAN}

Berdasarkan hasil dan pembahasan diatas, diketahui bahwa tingkat akurasi data Google Maps untuk pemenuhan variabel jumlah infrastruktur pada PODES secara umum masih rendah. Meskipun sudah cukup baik untuk Infrastruktur Kesehatan dan Tempat Ibadah dengan persentase di atas enam puluh persen, namun persentase ini masih cukup rendah untuk membuat data Google Maps dijadikan sebagai sumber data dalam pemenuhan variabel jumlah infrastruktur pada PODES. Selain itu ditemukan bahwa, data Google Maps belum dapat mengidentifikasi secara langsung infrastruktur puskesmas dan pasar berdasarkan fasilitas atau bangunan fisiknya. Untuk pemenuhan variabel jumlah infrastruktur puskesmas dan pasar lebih baik menggunakan kata kunci yang umum kemudian diidentifikasi termasuk dalam fasilitas atau bangunan fisik yang mana. Dan untuk tingkat akurasi titik koordinat data Google Maps sangat akurat sedangkan tingkat akurasi jarak yang diinformasikan Google Maps untuk pemenuhan variabel jarak infrastruktur perlu dilakukan penelitian lebih lanjut ke lapangan, namun tingkat akurasi jarak haversine dari data Google Maps sudah memiliki akurasi yang tinggi. Berdasarkan temuan-temuan tersebut, disimpulkan bahwa Google Maps belum dapat dimanfaatkan untuk pemenuhan variabel jumlah dan jarak infrastruktur pada PODES.

\section{DAFTAR PUSTAKA}

Annisa, C. F., \& Pramana, S. (2020). Kajian Pemanfaatan Data Google Maps dalam Official Sstatistics (Studi Kasus: Usaha Sektor Penyedia Makan Minum di Pulau Jawa dan Bali). Seminar Nasional Official Statistics 2020, 2020(1), 328-337.

Badan Pusat Statistik. (2018a). Pedoman Pencacah Desa/Kelurahan Podes 2018. Jakarta: Badan Pusat Statistik.

Badan Pusat Statistik. (2018b). Statistik Potensi Desa Indonesia 2018. Jakarta: Badan Pusat Statistik.

Banerjee, R. (2014). Website Scraping. In Happiest Mind Technologies. India: Happiest Minds Technologies.

De Mauro, A., Greco, M., \& Grimaldi, M. (2015). What is Big Data? A Consensual Definition and a Review of Key Research Topics. AIP Conference Proceedings, 1644(2015), 97-104.

Mukarromin, D. R., \& Nilogiri, A. (2020). Perbandingan Algortima Haversine dan Perhitungan Jarak Menggunakan Google Maps API pada Pemilihan Unit Pelaksana Teknis Dinas (UPTD) Terdekat Dengan Lokasi Pelaporan Kejadian Masyarakat Di Kabupaten Jember. Skripsi Universitas Muhammadiyah Jember. Jember.

Patrick. (2016). The Big Data Driving Google Maps | Oceans of Data. Oceans of Data Institute. Cited in http://oceansofdata.org/big-data-driving-google-maps. [5 Juli 2021]

PKL Politeknik Statistika STIS. (2020). Buku 11 Seri Laporan Hasil PKL 2019/2020: Pemanfaatan Bid Data dalam Pemenuhan Variabel Jarak dan Jumlah Infrastruktur pada Data Potensi Desa. Jakarta: Politeknik Statistika STIS.

Shukla, S., Kukade, V., \& Mujawar, S. (2015). Big Data: Concept, Handling and Challenges: An Overview. International Journal of Computer Applications, 114(11), 6-9.

Vale, S., \& Gjaltema, T. (2020). Classification of Types of Big Data. Classification of Types of Big Data UNECE Statswiki. Cited in

https://statswiki.unece.org/display/bigdata/Classification+of+Types+of+Big+Data. [5 Juli 2021] 